\title{
DYNAMICS OF MUSCULAR PERFORMANCE INDICES DURING THE 30-s VERTICAL JUMP TEST IN ENDURANCE AND SPRINT COHORTS
}

\author{
Eugenijus Trinkūnas, Alfonsas Buliuolis, Rita Sadzevičienė, Birutė Zacharienė
}

Lithuanian Academy of Physical Education, Kaunas, Lithuania

\begin{abstract}
Research background and hypothesis. According the methodological requirement testing procedures do not modify the main training objectives. It is well known that specificity of performance assessment tests is important if we want to compare performance of different groups tested.

Research aim was to find out the peculiarities of muscular performance indices in sprint and endurance cohorts while performing a 30 -s vertical jump test.

Research methods. The participants of the study were two groups of athletes, i. e. sprint and endurance runners. The participants of the study performed a 30-s vertical jumps test with maximal efforts. The sum of height of all jumps was calculated by a special computerized program and the values in height of jumps, contact time and relative power at onset of workload and at each 5 seconds of the test were analyzed.

Research results. The difference between the cohorts in jumps height was statistically significant $(\mathrm{p}<0.05)$ during the whole series of jumps. Athletes' adaptation to speed-power type of exercising produced higher anaerobic muscle performance indices while performing 30-s duration jumps test. Endurance runners usually demonstrate lower results in jumping than sprint- athletes and they compensate reduced muscular power with prolonged duration of take-off.

Discussion and conclusions. Despite some methodological limitations the results of this study show that the assessment of muscular performance indices allows assessing the peculiarities of dynamics of relative muscle power and fatigue.
\end{abstract}

Keywords: endurance and sprint running, muscular performance, vertical jump test.

\section{INTRODUCTION}

$\mathrm{I}$ is accepted that the best index of sports performance abilities is a competitive result and pedagogical, physiological, biochemical, psychological or other tests indicate only the factors on which sports results depend (Maud, Foster, 1995; Raslanas, 2000 et al.).

The exercise tests are widely used for the assessment of preparedness for performance of athletes and the changes in various stages of training. We tested the hypothesis that some muscular performance indices or their interplay should be more sensitive while comparing the groups with different type of exercising.

Testing procedures have clearly formulated methodological requirements so that a testing procedure could not modify the adaptation planned by the coach (Viru, A. M., Viru, M., 2004).

The 60-s vertical jump test suggested by Bosco was designed to determine the maximal anaerobic power, and based on the measurements of individual performance in a task of vertical jumps (Luthanen, Comi, 1978; Bosco et al., 1983; Narita, Anderson, 1992; Bosco, 2000). This test is very popular and usually used to assess muscle functional performance of athletes. Special research on the functional changes of the 
cardiovascular system was carried out using Bosco test and the modified version of it of this test, i. e. the 30-s vertical jump test (Poderys et al., 2005, 2010). $60 \mathrm{~s}$ vertical jump test is a very difficult test, so this testing procedure is recommended only for well prepared athletes to determine the changes in their anaerobic capacity. The shorter variant of testing is recommended to determine the abilities of non-trained persons. Authors suggest to apply a 30-s duration vertical jump test (Buliuolis, 2006). In this study we analyzed the peculiarities of muscular performance indices during 30 - $\mathrm{s}$ vertical jump test. The aim of this study was to find out the peculiarities of muscular performance indices in sprint and endurance cohorts while performing a 30 -s vertical jump test.

\section{RESEARCH METHODS}

The participants of the study were students from various Lithuanian universities, athletes of different running events, i. e. runners in sprint or endurance events and candidates of Track and Field Athletics team of Kaunas, some of them were top or near-top athletes. The athletes were divided in to endurance and sprint cohorts (Table). After a warm-up and short recovery time the athletes performed a 30 -s vertical jump test with maximal efforts. The height, push-off and relative power of jumps were registered and analyzed.

During this test, the subjects stood up on a contact platform and performed a 30 -s vertical jump test with maximal efforts. The jumps were performed without active swings by hands. To measure the height of jumps, the contact platform was connected with a PC. The sum of the height of all jumps $(\Sigma)$ was calculated by a special computerized program. Then muscular performance indices were analyzed: the values of the height of jumps, contact time and relative power at onset of workload and at each 5 seconds of the test.

Table 1. Characteristics of research participants

\begin{tabular}{|l|c|c|}
\hline \multicolumn{1}{|c|}{ Indices } & Sprint & Endurance \\
\hline Number of participants (n) & 30 & 23 \\
\hline Age, years & $20.9 \pm 0.3$ & $20.7 \pm 0.4$ \\
\hline Height, cm & $182.6 \pm 1.1$ & $180.1 \pm 1.2$ \\
\hline Weight, kg & $76.2 \pm 1.1$ & $70.6 \pm 1.1$ \\
\hline BMI, kg/m ${ }^{2}$ & $22.9 \pm 0.3$ & $21.7 \pm 0.3$ \\
\hline
\end{tabular}

Note. (Means $\pm \mathrm{SE})$.

Statistical analysis. The research data were processed using Microsoft Excel 2007 program for mathematical statistical analysis. Descriptive data are presented as means $\pm \mathrm{SE}$. The mean peak torque was compared between cohorts using Student's $t$ test. The level for statistical significance was set to an alpha level of $\mathrm{p}<0.05$.

\section{RESEARCH RESULTS}

The computerized program registered and presented the absolute values and dynamics of averaged results in height of jumps, relative muscle power, the sum of jump height, the number of jumps, and the decrease in jump performance indices. The results obtained in the study showed that the mean values of jump height in the sprinters cohort at the beginning of the workload were $(45.4 \pm 0.9 \mathrm{~cm})$, and it was significantly greater than in the endurance runners cohort $(34.9 \pm 1.1 \mathrm{~cm})$ (Figure 1). The difference was statically significant $(\mathrm{p}<0.05)$.
Figure 1. Dynamics of jumps height while performing 30-s jump test

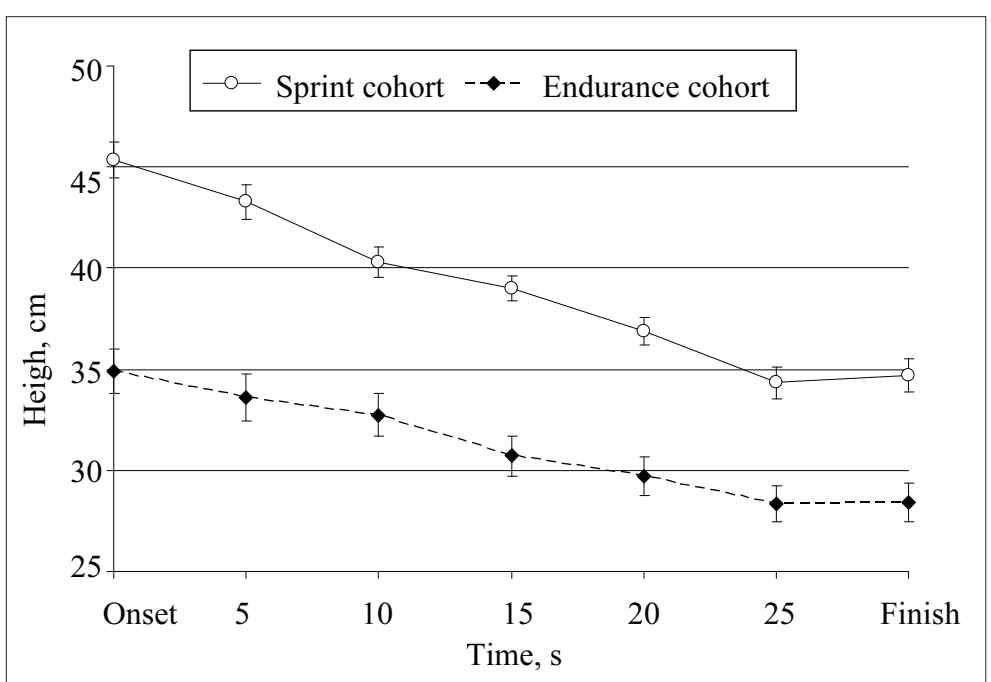




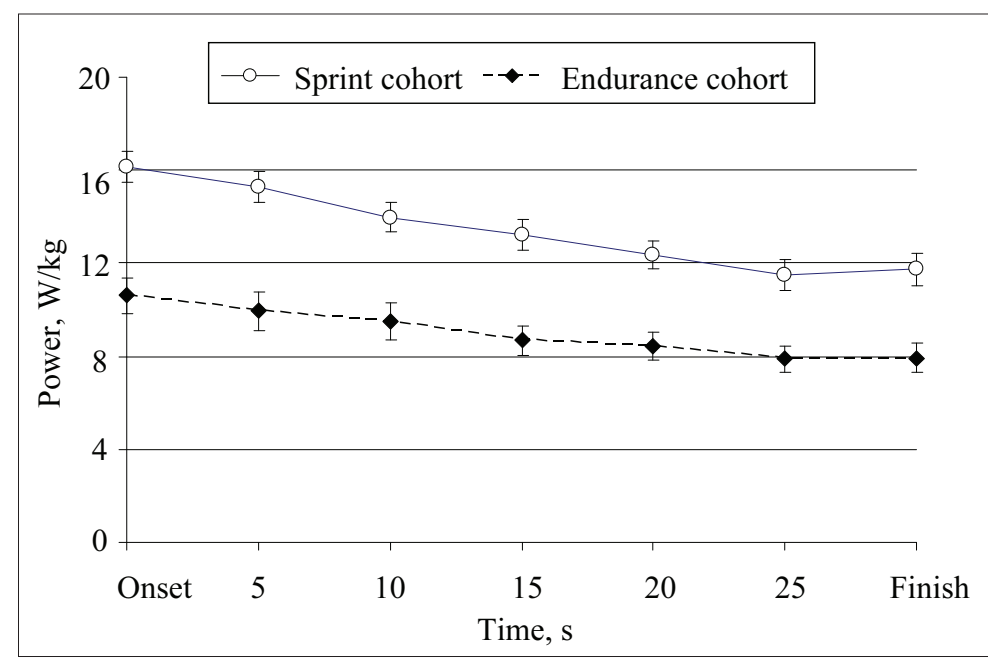

Figure 2. Dynamics of relative muscle power while performing 30-s jumps test

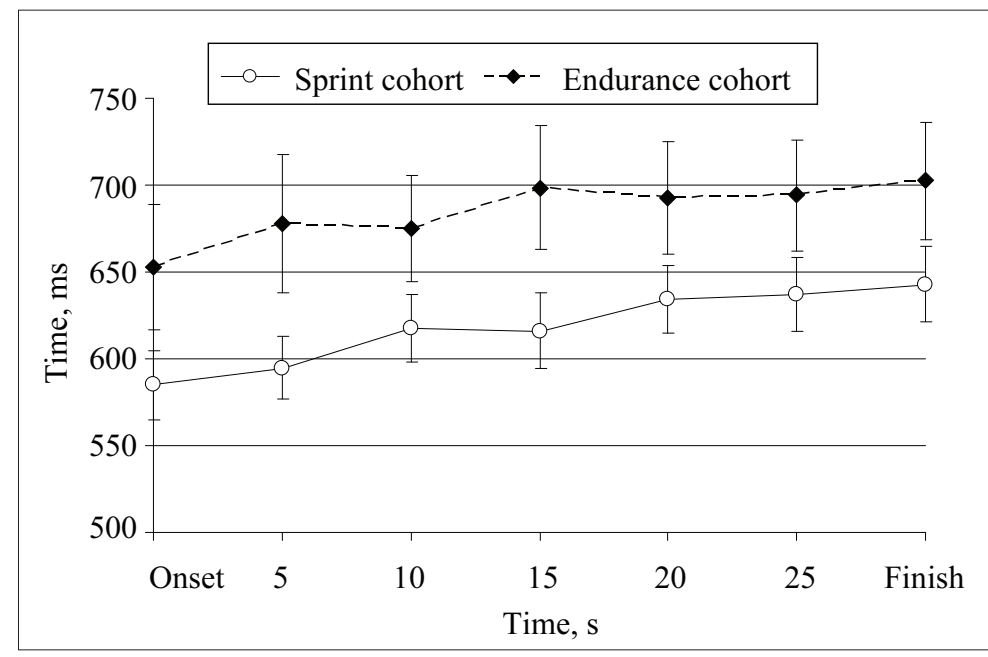

Figure 3. Duration of take-off while performing 30-s duration jump test

The averaged values of jump height registered every five seconds during the workload decreased in both experimental groups. The difference between the cohorts in jump height remained statistically significant $(p<0.05)$ during the whole series of jumps. At the end of the series sprinters were able to jump $34.7 \pm 0.8 \mathrm{~cm}$, and endurance athletes $-28.4 \pm 1.0 \mathrm{~cm}$.

The changes in relative muscle power during whole jumping test had a similar trend as the jump height in both experimental cohorts. Accordingly, in the series of jumps at the beginning of the workload, the sprinters were able to develop $16.1 \pm$ $0.7 \mathrm{~W} / \mathrm{kg}$, and $10.6 \pm 0.8 \mathrm{~W} / \mathrm{kg}$ - endurance runners (Figure 2). At the end of the series of jumps, the relative power values were reduced, respectively $-11.7 \pm 0.7 \mathrm{~W} / \mathrm{kg}$ (sprint cohort) and $7.9 \pm 0.6 \mathrm{~W} / \mathrm{kg}$ (endurance cohort). The difference was statistically significant $(\mathrm{p}<0.05)$.
While comparing the decline between the groups in the speed of jump height and relative muscle power during the whole testing procedure, we found that sprinters' jump height decreased by $24.1 \pm 1.3 \%$ and the relative power of $-28.7 \pm$ $2.0 \%$. In endurance runners cohort the jump height decreased by $18.5 \pm 1.7 \%$, while the relative power decreased by $24.0 \pm 3.3 \%$. Both groups performed the same number of jump during the workload: sprinters $-26.8 \pm 0.4$, and endurance athletes $26.7 \pm 0.5$ jumps. However, the sum of height in sprinters' group was higher, i. e. $1029.8 \pm 24.8$ $\mathrm{cm}$, endurance runners $-815.7 \pm 33.9 \mathrm{~cm}$. This difference was statically significant $(\mathrm{p}<0.05)$. The amount of relative muscle power while performing 30-s maximal jumping series, was also statistically different between the groups $(\mathrm{p}<0.05)$. A total sum of all jumps in relative muscular power were as follows: sprinters cohort $347.1 \pm 19.9 \mathrm{~W} / \mathrm{kg}$ and 
endurance runners cohort $-225.4 \pm 19.6 \mathrm{~W} / \mathrm{kg}$. Figure 3 shows that the contact time in sprinters cohort increased with the development of fatigue from $584.8 \pm 19.9 \mathrm{~ms}$ up to $643.0 \pm 22.1 \mathrm{~ms}$ and in endurance cohort from $652.9 \pm 36.1 \mathrm{~ms}$ up to 702.5 $\pm 33.7 \mathrm{~ms}$, respectively.

\section{DISCUSSION}

Vertical jump test required involvement of main muscle groups. In literature we can find some data concerning the importance of participation of various muscle groups during the jumps. C. L. Hubley and R. P. Wells (1983) present the data that for performance of a vertical jump with a take-off with both legs without swinging arms muscles performing the thigh movement (buttocks, etc.) gave approximately $28 \%$; thigh muscles (calve movement) $-49 \%$ and calf muscles (foot movement) - $23 \%$ of energy. Australian researcher (Blight, 1994) presented the data about the contribution of various muscles to performance of a single vertical jump with active swing by arms. The active muscules include the primary (main) muscles, i. e. quadriceps $-33 \%$; secondary muscles, i. e. thigh spinal muscles $27 \%$ and buttock muscle $-5 \%$; muscles bending the foot $-7 \%$, back spinal muscles ( $m$. deltaic, m. trapezium) $-18 \%$; and tertiary_muscles, i. e. other muscles of the body $-10 \%$. So, the vertical jump could be an integral power index of the whole-body muscles.

Muscles can adapt to workloads performed during the training session - short-term or fast adaptation and to regular exercising - longterm adaptation (Häkkinen, 1994; Pette, 1986; Skurvydas, 1991). Muscle adapts differently to strength, power, and speed or endurance type of exercising (Häkkinen, 1994; Maio Alves et al., 2010; Nimphius et al., 2010). Results obtained during this study showed that persons having adapted to speed and power type of loads could be characterized with ability to demonstrate a higher muscle performance index and to perform shortterm exercising with maximal efforts than the persons adapted to endurance type of exercising.

The results of our research demonstrated that athletes with different type of long-term adaptation showed that subjects were able to demonstrate different results in high of jumps. Endurance runners usually demonstrate a lower result in jumping than sprinters and the reduction in muscular power is compensated by the prolonged duration of contact time.

These results have demonstrated well-known fact that the specificity of workload during the testing procedure is an important factor when the task is to compare the performance abilities between different cohorts.

We found that the absolute values of all measured muscular performance indices were higher in sprint cohort. Such an unambiguous gain between participants of sprint cohort was like an advantage for anaerobic performance. There was no doubt that athletes, adapted to endurance physical loads, would have an advantage in the assessment of the other aspects of muscular performance, such as endurance or economy during long-term tasks.

Research literature suggests that the assessment of anaerobic working-capacity needs to choose the duration of testing workload depending on athlete's specialization. For example, in the assessment of sprinters, muscular performance should take shorter workloads compared to endurance athletes (Maud, Foster, 1995; Taylor, Romer, 2008).

In conclusion, the results of this study show that despite some methodological limitations mentioned above the assessment of muscular performance indices allows assessing the peculiarities of dynamics of relative muscle power and fatigue.

\section{CONCLUSION AND PERSPECTIVES}

Athletes, who have adapted to speed-power type of exercising, demonstrate higher anaerobic muscle performance indices while performing 30-s duration jump test than endurance athletes. Endurance runners usually demonstrate a lower result during the jumping test than sprinters and the reduction in muscular power in compensated by prolonged duration of contact time. 


\title{
REFERENCES
}

Blight, G. (1994). Developing power and optimising volleyball performance. Australian Volleyball Magazine, 7-40.

Bosco, C., Luthanen, P., Komi, P. (1983). A simple method for measurement of mechanical power in jumping. European Journal of Applied Physiology, 50, 273-282.

Bosco, C. (2000). Strength Assessment with the Bosco's Test. Roma: Italian Society of Sport Science.

Buliuolis, A. (2006). Širdies ir kraujagysliu sistemos funkcijos mobilizacijos ir atsigavimo ypatybès atliekant anaerobinius krūvius: daktaro disertacija. Kaunas: LKKA.

Christopher, J. (2000). Physiological Tests for Elite Athletes/Australian Sports Commission. Human Kinetics.

Häkkinen, K. (1994). Neuromuscular adaptation during strength training, aging, detraining and immobilization. Critical Rev. in Physical and Rehabililitation Medicine, 6 (3), 161-198.

Hubley, C. L, Wells, R. P. (1983). A work-energy approach to determine individual joint contributions to vertical jump performance. European Journal Applied Physiology and Occupational Physiology, 50 (2), 24754.

Luthanen, P., Comi, P. V. (1978). Segmental contribution to forces in vertical jumping. European Journal of Applied Physiology, 38, 181-188.

Maio Alves, J. M., Rebelo, A. N., Abrantes, C., Sampaio, J. (2010). Short-term effects of complex and contrast training in soccer players vertical jump, sprint, and agility abilities. Journal of Strength and Conditioning Research, 24 (4), 936-941.

Maud, P. J., Foster, C. (1995). Physiological Assessment of Human Fitness. USA: Human Kinetics. P. 73-85.
Narita, S., Anderson, T. (1992). Effects of upper body strength training on vertical jumping ability of high school volleyball players. Sports Medicine, Training and Rehabilitation, 3, 33.

Nimphius, S., McGuigan, M. R., Newton, R. U. (2010). Relationship between strength, power, speed, and change of direction performance of female softball players. Journal of Strength and Conditioning Research, 24 (4), 885-895.

Pette, D. (1986). Regulation of Phenotype Expression in Skeletal Muscle Fibbers by Increased Contractile Activity. Champaign IL. P. 3-27.

Poderys, J., Buliuolis, A., Poderytė, K., Sadzevičienė, R. (2005). Mobilization of cardiovascular function during the constant-load and all-out exercise tests. Medicina, 12 (41), 1048-1053.

Poderys, J., Venskaityte, E., Poderienė, K., Buliuolis, A., Vainoras, A. (2010). Functional state assessment on the dynamics of interparametric concatenations during exercise tests. Medicina, 46 (6), 429-434.

Raslanas, A. (2000). Lietuvos sportininkų rengimo priešvaržybiniais makrociklais ir mezociklais valdymo ypatumai siekiant geriausios sportinès formos Sidnèjaus olimpinèse žaidynèse. Sportininku aklimatizacija bei adaptacija Sidnejuje. Biuletenis, 2, 5-9.

Skurvydas, A. (1991). Organizmo adaptacijos prie pagrindiniu fiziniu krūviu pagrindiniai dèsningumai. Vilnius.

Taylor, B. J., Romer, L. M. (2008). Effect of expiratory muscle fatigue on exercise tolerance and locomotor fatigue in healthy humans. Journal Applied Physiology, 104 (5), 1442-1451.

Viru, A. M., Viru, M. (2004). The analysis of peak performance in the physiological aspect. Ugdymas. Küno kultūra. Sportas, 4, 5-9.

\section{GREITUMĄ IR IŠTVERMĘ LAVINANČIŲ SPORTININKŲ RAUMENU DARBINGUMO RODIKLIU KAITA ATLIEKANT $30 \mathrm{~S}$ TRUKMĖS VERTIKALAUS ŠUOLIAVIMO TESTĄ}

\author{
Eugenijus Trinkūnas, Alfonsas Buliuolis, Rita Sadzevičienė, Birutė Zacharienė \\ Lietuvos kūno kultūros akademija, Kaunas, Lietuva
}

\section{SANTRAUKA}

Tyrimo pagrindimas ir hipotezė. Vertinant sportuojančiuju parengtumą ir jo pokyčius po treniruotès etapo taikomi fizinio krūvio mėginiai, kuriu metu greitai pavargstama. Suformuluotas aiškus metodinis reikalavimas, kad testavimo procedūra neturi modifikuoti treniruotes tikslų. Gerai žinoma, kad darbingumo vertinimo testu specifiškumas yra reikšmingas tada, kai norime palyginti skirtingų tiriamuju grupių darbingumą.

Tikslas - nustatyti sprinto ir ištvermès bėgikų raumenų darbingumo rodiklių kaitos ypatybes atliekant $30 \mathrm{~s}$ trukmès vertikalaus šuoliavimo testą. 
Metodai. Buvo tiriami lengvaatlečiai bėgikai (sprinto ir ištvermès grupès). Tiriamieji atliko $30 \mathrm{~s}$ trukmès vertikalaus šuoliavimo testą didžiausiomis pastangomis. Sportininkui šuoliuojant ant kontaktinès platformos, vertinome šuolio aukščio, santykinio galingumo, jų mažejimo spartos, atremties fazès trukmès rodiklius, skaičiavome visų atliktų šuolių aukščio sumą.

Rezultatai. Visos šuolių serijos metu abiejų tiriamuju grupių, šuolių aukščio vidutinės reikšmės, užregistruotos kas penkias sekundes, mažejo. Lyginant abi tiriamuju grupes, šuolių aukščio vidutiniu reikšmių skirtumas išliko statistiškai reikšmingas $(p<0,05)$ visos šuolių serijos metu. Abiejų tiriamujų grupių raumenų santykinio galingumo kaita serijos metu turejjo panašią tendenciją. Šuolių serijos metu nustatėme, kad sprinterių grupèje šuolio aukštis ir santykinis galingumas mažèjo didesne sparta nei ištvermès bėgikų. Viso šuolių testo metu atsispyrimo trukmė buvo kur kas ilgesnè ištvermès bėgiku grupejje.

Aptarimas ir išvados. Nepaisant kai kurių metodinių apribojimų, vertikalaus šuoliavimo testas, sukuriantis greitai besivystančio nuovargio sąlygas, leidžia vertinti sportuojančiojo raumenų santykinio galingumo, nuovargio ir jų kaitos ypatybes. Prie greitumo krūvių adaptavęsi asmenys pasiekia reikšmingai didesnių raumenų darbingumo rodiklių nei ištvermès šakų sportininkai. Atlikdami fizinio krūvio užduotis greitai besivystančio nuovargio sąlygomis ištvermès bėgikai mažejantị raumenų susitraukimo galingumą kompensuoja atremties fazès trukmès pailginimu daugiau nei sprinteriai.

Raktažodžiai: ištvermès ir sprinto bẻgimas, raumenų darbingumas, vertikalių šuolių testas.

Gauta 2011 m. lapkričio 9 d.

Received on November 9, 2011

Priimta 2011 m. gruodžio 8 d.

Accepted on December 8, 2011

Corresponding author Eugenijus Trinkūnas Lithuanian Academy of Physical Education Sporto str. 6, LT-44221 Kaunas

Lithuania

Tel +37068639859

E-mail e.trinkunas@lkka.1t 